Ayurlog: National Journal of Research in Ayurved Science http://www.ayurlog.com Volume: $6^{\text {th }} \mid$ Issue: $5^{\text {th }} \mid$ August 2018

\title{
Author Understanding role of three ficus species in the management of skin diseases with respect to pittaj kushtha
}

\author{
Kulkarni D.V.*1, Kudale Ruchita Raghunath ${ }^{2}$, Pawar Renuka Shahaji ${ }^{3}$
}

1. Professor and Head of Dept.,

2. P. G. Scholar,

3. P. G. Scholar,

Dravyaguna Dept., Government Ayurvedic College, Osmanabad, Maharashtra

*Corresponding author: e mail: dvkulkarni13@gmail.com

\section{ABSTRACT}

Skin diseases are most common form of infections. Due to changes in lifestyle, food habits and different causative organisms; the occurrence of skin diseases is increasing day by day. While treating of skin diseases, with the help of modern. science, success is mixed with lot hazards. In Ayurveda, all skin diseases are described under the title-'Kushtha'. Many medicinal plants are described in treatment of Kushtha according to its type. Nyagrodha (Ficus benghalensis), Ashvattha (Ficus religiosa) and Udumbara (Ficus racemosa) are the plants belonging to Moraceae family and Ficus species. These are classified under the Mishrak gana viz. - Panchvalkala Vruksh and Panchkshiri Vruksh, which are used for the treatment of Pittaj kushtha since ages. All these three drugs are in possession of Kashaya Rasa, Katu Vipaka and Sheeta Veerya along with Ruksha guna. Kashaya rasa is composed of Prithvi and Vayu mahabhuta and is responsible for Kledshoshak activity. Kashaya rasa and Sheeta veerya have Pittaghna and Stambhak action by which it reduces kleda which is one of the main Dushyas in Kushtha. Ruksha guna act as kled and strav shoshak. Use of Nyagrodha, Ashvattha and Udumbara may found beneficial in treatment of Pittaj Kushtha. As these drugs are easily available and cost effective; they may offer a helping hand for the poor patients suffering from skin diseases. This review reveals their role in Pittaj Kushtha.

Keywords: - Skin diseases, Ficus species, ittaj kushtha.

\section{INTRODUCTION}

Skin is the largest organ of body consisting three layers of tissues- epidermis, dermis and sub-cutaneous layer. It is responsible for various activities of body including temperature regulation, insulation, sensation, synthesis of vitamin $\mathrm{D}$ and protection of body from different organisms ${ }^{[1]}$. Due to changes in life style and different causative organisms; occurrence of skin diseases is increasing day by day. It is one of the most common human illness occurring in both high and low income categories.

Ayurveda states that overall condition of individual is responsible for healthy skin. Numerous skin care treatments and medicinal plants are described according to one's prakriti. According to Ayurveda, any alteration in healthy life style and food habits may result in occurrence of skin diseases i.e. 'Kushtha'. It is a broad term used to denote skin diseases in Samhitas. 
All types of skin diseases are included in this term.

Ayurvedic literature consists of various medicinal plants which are beneficial in treatment of Kushtha. Nyagrodha (Ficus benghalensis), Ashvattha (Ficus religiosa) and Udumbara (Ficus racemosa) are the plants used for treating Pittaj kushtha since ages. These three are included in Mishrak gana viz.-

Table 1-Mishrak Gana described in Samhitas

\begin{tabular}{|l|l|}
\hline Mishrak Gana & Described by \\
\hline Panchvalkala & Acharya \\
Vruksh, Panchkshiri & Bhavprakasha \\
Vruksh & \\
\hline Panchvetas & Raj Nighantu $^{[3]}$ \\
\hline Nyagrodhadi gana & $\begin{array}{l}\text { Acharya } \\
\text { Sushruta }\end{array}$ \\
& Acharya \\
& Vagbhata $^{[5]}$ \\
\hline Kashayskandh & ${\text { Acharya } \text { Charak }^{[6]}}$ \\
\hline
\end{tabular}

These drugs act according to the Rasapanchaka and causés Sampraptibhang leading to cure of Kushtha.

\section{AIM-}

- Understanding role of three ficus species in the management of skin diseases with respect to pittaj kushtha.

\section{OBJECTIVES-}

- To study Nyagrodha, Ashwattha, Udumbara for their role in treatment of Skin diseases as per Ayurvedic perspective.

- To study the Rasa, guna, virya, vipaka of Nyagrodha, Ashwattha, Udumbara.

- To study current research conducted on Nyagrodha, Ashwattha, Udumbara.
Along with Tridosha (Vata, Pitta and Kapha); Twacha, Rakta, Mamsa and Lasika are seven dushyas responsible for Kushtha. Depending on these; seven types of Mahakushtha and eleven types of Kshudrakushtha are described by Acharya Charaka in Charak Samhita ${ }^{[6]}$.

Among the eighteen types, fourteen are having dominance Pitta dosha. Pittaj kushtha have the symptoms as- Daha, Raga, Paristrava, Paaka, Visra gandh, Kleda, Vrana, Lalima, Strava etc. ${ }^{[6]}$. Occurrence of these symptoms may vary from patient to patient.

Among the Panchvalkala vruksha; Nyagrodha, Ashvattha and Udumbara are most commonly found in our surrounding. They belong to Moraceae family and Ficus species having taxonomical classification as follows-

Table 2- Taxonomy of Ficus species

\begin{tabular}{|l|l}
\hline Kingdom & Plantae \\
\hline
\end{tabular}

\begin{tabular}{|l|l} 
Sivision & Magnoliophyta
\end{tabular}

Class $\quad$ Magnolipsida

\begin{tabular}{|l|l|}
\hline Order & Urticales \\
\hline Family & Moraceae \\
\hline Genus & Ficus \\
\hline
\end{tabular}

Description of these drugs on basis of their rasa, veerya, vipaka, guna is as follows-

\section{Nyagrodha}

Latin name- Ficus bengalensis Linn.

Doshaghnata- Kapha-pittaghna ${ }^{[2]}$

Actions described in Samhitas ${ }^{[2]}$.

1. Vranapaha

2. Varnya

3. Dahaghna

\section{Pharmacological actions-}

1. Rimi Shukla SGJG and others studied the antioxidant effect of aqueous extract of the bark of 
Ficus benghalensis and found that it has extreme scavenging activity by DPPH radical ${ }^{[7]}$.

2. Biswas TK MB described Ficus benghalensis for its wound healing activity when tested in various experimental models ${ }^{[8]}$.

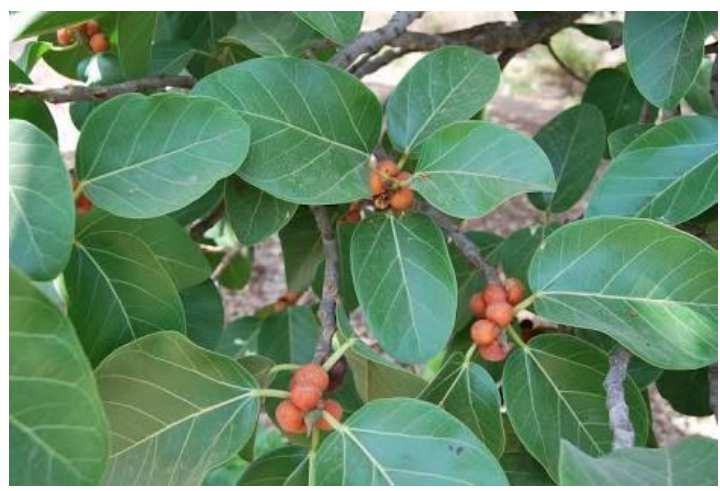

Figure 1- Nyagrodha (Ficus bengalensis Linn.)

\section{Ashvattha}

Latin name- Ficus religiosa Linn.

Doshaghnata- Pitta-kaphaghna ${ }^{[2]}$

Actions described in Samhitas ${ }^{[2]}$.

1. Vranaghna

2. Varnya

3. Raktavikarshamak

\section{Pharmacological actions-}

1. Jiwala SA and others done the evaluation of free radical scavenging activity and found that Ficus religiosa is rich with phytochemical contents having antioxidant activity ${ }^{[9]}$.

2. R.Preethi and others studied aqueous extract of Ficus religiosa and found that the growth of P.aeruginosa was remarkably inhibited by it ${ }^{[10]}$.

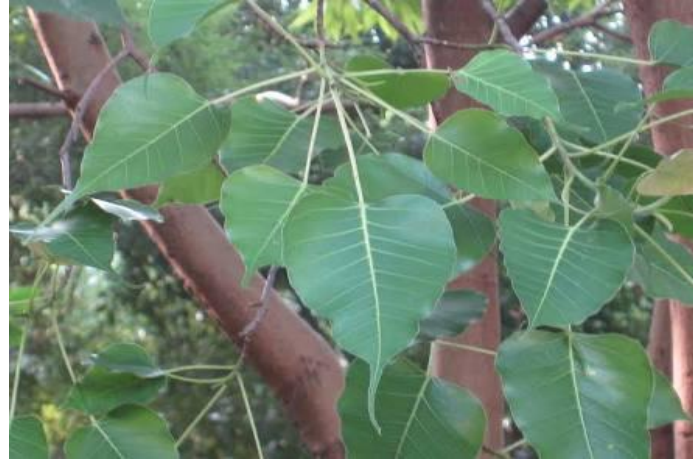

Figure 2- Ashvattha (Ficus religiosa Linn.)

\section{Udumbara}

Latin name- Ficus racemosa Linn.

Doshaghnata- Pitta-Kaphaghna ${ }^{[2]}$

Actions described in Samhitas ${ }^{[2]}$.

1. Vranashodhan-Ropan

2. Varnya

3. Raktavikarshamak

\section{Pharmacological actions-}

1. V.P.Veerapur and others studied the antioxidant

activity of Ficus racemosa stem bark extract and

found that ethanol extract exhibits significantly higher steady state antioxidant activity ${ }^{[11]}$.

2. R.B.Rao and others found that ethanol extract of stem bark of Ficus racemosa shows wound healing activity in incised and excised wound in rats ${ }^{[12]}$.

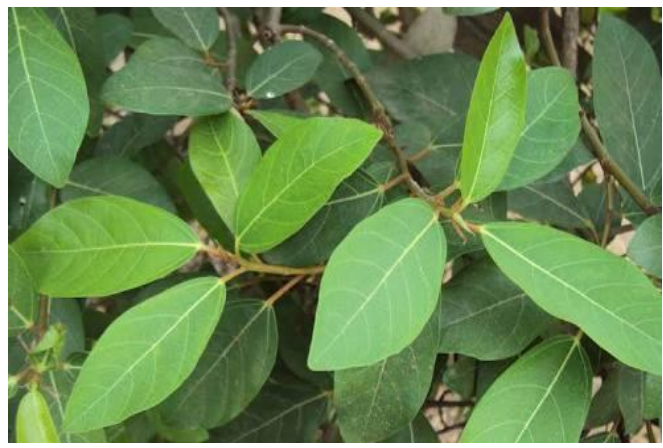

Figure 3- Udumbara (Ficus racemosa Linn.) 


\section{DISCUSSION-}

\section{Rasapanchaka of Nyagrodha, Ashwattha, Udumbara-}

Table 3- Raspanchaka of Nyagrodha, Ashwattha, Udumbara

\begin{tabular}{|l|l|l|l|l|}
\hline Drug name & Rasa & Veerya & Guna & Mahabhuta \\
\hline Nyagrodha & Kashaya & Sheeta & Ruksha, Guru & Pruthvi, Vayu \\
\hline Ashwattha & Kashaya, Madhur & Sheeta & Ruksha, Guru & Pruthvi, Vayu, Jala \\
\hline Udumbara & Kashaya & Sheeta & Ruksha, Guru & Pruthvi, Vayu \\
\hline
\end{tabular}

\section{Comparison of Rasa :}

From above table we can clearly see that, Kashaya rasa is mostly present in all the drugs. They also have Madhur rasa in

\section{Comparison of Guna:}

All the three drugs are having Ruksha and Guru Guna.

\section{Comparison of Mahabhuta:}

All these three drugs have Pruthvi and Vayu mahabhuta. Jala mahabhuta is als present in one of them.

\section{Samprapti of Pittaj Kushtha-}

Along with Tridosha (Vata, Pitta and Kapha); Twacha, Rakta, Mamsa and Lasika are 7 dushyas responsible for Kushtha. Due to dominance of increased Pitta Dosha leads to increase Ushna and Snigdha guna. This causes the symptoms like- redness of skin, Daha, Raga, Paka, Kleda, Vrana formation, discharge of Rakta-Pooya-Lasika from skin etc.

Here we need to use drugs of Sheeta and Ruksha guna which will reduce Ushna and Snigdha guna and ultimately cure the Pittaj kushtha.

Among all these three drugs; there is dominance of kashaya rasa, Sheet veerya and Ruksha,Guru guna. They also have dominance of Pruthvi and Vayu Mahabhutas. Kashaya rasa has Pittaghna, Stotoshodhak, Kledshoshak, them. Thus Kashaya rasa is present $82.5 \%$ and that of Madhur rasa is $17.5 \%$.

\section{Comparison of Veerya:}

All the three drugs are having Sheet veerya.

Twakprasadak, Vranropak activity. With these; increased Pitta dosha, Strotorodha, kleda in Pittaj kushtha decreases. Twakprasadana and healing of vrana takes place. Also madhur rasa performs its varnya activity and Pittaj kushtha is ealed.

Sheeta veerya decreases daha, paka and raga present in Pittaj kushtha and Ruksha guna absorbs the kleda and strava. Thus helps in reducing Pittaj kushtha.

Due to dominance of Pruthvi and Vayu mahabhuta; Stravashoshaka and kledachushana is done. These drugs also have Jala Mahabhuta in minor quantity.

\section{CONCLUSION}

The present study reveals that these three herbs dominantly having Kashaya Rasa, Sheeta veerya, Ruksha guna and play significant role in treatment of Pittaj Kushtha.

\section{REFERENCES-}

1) Balne Vijay Kumar, Shruti Bokare, Review of skin infections (Twak rogas) and its natural solutions, International Ayurvedic Medical 
Journal, Vol.2, Issue 6, NovemberDecember-2014, ISSN:2320 5091, Pg no.- 949-951.

2) Padmashree Prof. Krushnachandra Chunekar, Vatati Varga, Bhavaprakash Nighantu, Reprint 2015, Varanasi, Chaukhambha Bharati Akadami, 2015 , Page no.- 501-505

3) Dr. Indradev Tripathi, Mishrakadi Varga, Raj Nighantu, Trutiya sanskaran 2003, Varanasi, Chaukhambha Krushnadas Acadamy, 2003, Pg no.-661

4) Vaidyaraj Datto Ballal Borkar, Dravyasangrahaniya adhyaya, Sarth Sushrut Samhita, Pune, Rajesh Ramesh Raghuvanshi, Page no.- 155

5) Dr.Ganesh Krushna Garde, Shodhanadigansangraha adhyaya, Sarth Vagbhat, New Edition- 2009, Pune, Rajesh Ramesh Raghuvanshi, 2009, Page no.- 69

6) Prof.Dr.Y.G.Joshi, Rogbhishakjitiy adhyaya, Charaksamhita, Poorvardha, $4^{\text {th }}$ edition, Pune, Vaidyamitr Prakashan, 2009, Page no.-616

7) Rimi Shukla SGJG, Prabhu KM, Murthy PS, Antioxidant effect of aqueous extract of the bark of Ficus benghalensis in hypercholesterolaemic rabbits, Journal of Ethnopharmacy, 41, 1994, 71-76

8) Biswas TK MB, Plant medicines of Indian origin for wound healing activity: A review Int Journal Low Extreme Wounds, 2(1), 2003, 25-39

9) Jiwala SA, Bagul MS, Parabia $M$ and Rajani M., Evaluation of free radical scavenging activity of an ayurvedic formulation, Indian J Pharm Sci. 2008; 70:31-35

10) R.Preethi, V.Vimal Devanathan and M. Loganathan, Antimicrobial and antioxidant efficacy of some medicinal plants against food borne pathogens, Advances in biological research,4(2): 122-125, (2010)

11) V.P.Veerapur, K.R. Prabhakar, V.K. Parihar, et al, Ficus racemosa stem bark extract: a potent antioxidant and a probable natural radioprotector, Evid Based Complement Altern Med, 2009, 6, 317-324

2) R.B.Rao, K.Anupama, K.R.Swaroop, T.Murugesan, M.Pal, S.C. Mandal, Evaluation of anti-pyretic potential of Ficus racemosa bark, Phytomedicine, 2002, 9, 731-733

Understanding role of three ficus species in the management of skin diseases with respect to pittaj kushtha

Kulkarni D.V., Kudale Ruchita Raghunath, Pawar Renuka Shahaji

Ayurlog: National Journal of Research in Ayurved Science- 2018; (6)(5): 1-5 